\title{
Phenotypic and genetic diversity of Erwinia amylovora: the causal agent of fire blight
}

\author{
Joanna Puławska $\cdot$ Piotr Sobiczewski
}

Received: 30 March 2011/Revised: 6 October 2011/Accepted: 12 October 2011/Published online: 3 November 2011

(C) Springer-Verlag 2011

\begin{abstract}
Erwinia amylovora is a polyphagous bacterium causing fire blight on apple, pear and over 130 other plant species belonging mainly to the Rosaceae family. Although E. amylovora is regarded as a very homogenous species, the particular strains can differ in pathogenic ability as far as their host range is concerned (e.g. those originating from Rubus or Maloidae plants) as well as by the extent of the disease they cause. It was found that strains originating from North America are generally more genetically heterogeneous than those from Europe. Diversity of E. amylovora is also related to streptomycin resistance as a result of its application to control of fire blight. The level of genetic heterogeneity of E. amylovora is so low (comparative genome analysis revealed a similarity of over $99 \%$ for the two genomes tested) that standard DNA-based techniques fail in detection of intra-species variability. Amplified fragment length polymorphism was found to be most useful for differentiation of strains of fire blight causal agent as well as techniques ensuing release of pangenome sequences of two E. amylovora strains: multi-locus variable number of tandem repeats analysis and clustered regularly interspaced short palindrome repeats.
\end{abstract}

Keywords Chromosomal DNA - Erwinia amylovora . Phenotypic characters · Plasmid DNA · Virulence

Communicated by D. Treutter.

A contribution to the Special Issue: Pome Fruit Health.

J. Puławska $(\bowtie) \cdot$ P. Sobiczewski

Pomology Division, Research Institute of Horticulture,

ul. Pomologiczna 18, 96-100 Skierniewice, Poland

e-mail: joanna.pulawska@inhort.pl

\section{Introduction}

Biodiversity of bacterial plant pathogens is a result of their variability. This variability is caused by both environmental conditions leading to not fully hereditary changes in phenotype, and variation in the genetic material (Agrios 2005). Changes in genotype can influence the pathogenicity of bacteria such as a reduction or increase of bacterial virulence including an acquired ability to infect plant species, which were originally resistant to disease caused by particular bacterium. This constitutes a major obstacle to the culturing of resistant cultivars. Variability of pathogens can also cause the induction of resistance to pesticides, especially antibiotics (reviewed by Jones and Schnabel 2000).

Assessment of the genetic diversity of pathogens is important in epidemiological studies on e.g.: pathogen spread, the resistance breeding of plants to diseases, plant protection and quarantine. The selection of groups of pathogens in order to measure the effectiveness of various factors in protecting plants against diseases is also necessary. Data from studies of genetic diversity can be used to monitor the prevalence of pathogenic strains, detection and identification of possible sources of primary infection, mapping genes of bacteria and plants, and identification of individual strains in the study on population genetics, phylogenetic studies, and biogeography. Techniques used in studies on genetic diversity provide information helpful in distinguishing the strains as well as the phylogenetic relationship between the strains.

The development of molecular techniques has allowed the variation in the genetic material of bacteria pathogenic to plants to be revealed, both in their chromosome and plasmid DNA. There has been intensive work in this area on Erwinia amylovora (reviewed by Vanneste 1995; reviewed by Momol and Aldwinckle 2000; Kim et al. 2001; 
Gehring et al. 2011). This pathogen has caused great economic loss in many areas of apple and pear tree cultivation as well as areas where other host plants are cultivated.

\section{Phenotypic features}

\section{Host range and virulence}

Erwinia amylovora is a pathogen of more than 130 plant species belonging to 40 genera, mainly from the family Rosaceae (Van der Zwet and Keil 1979). Disease can occur on pear (Pyrus spp.), apple (Malus spp.) and quince (Cydonia spp.) trees as well as on hawthorn (Crataegus spp.), sorb (Sorbus spp.), cotoneaster (Cotoneaster spp.), serviceberry (Amelanchier spp.), firethorn (Pyracantha spp.), loquat (Eriobotrya japonica), medlar (Mespilus spp.), Stranvaesia spp. and photinia (Photinia spp.). It is generally believed that E. amylovora is a homogeneous species and does not show pathogenic specialization. This means that each isolate of the pathogen is potentially able to infect any of the known host plants (Momol and Aldwinckle 2000). However, in an artificial inoculation experiment, De Ley et al. (1984) have shown that different isolates may exhibit some variations in host range. Isolates from plants of the genus Rubus are particularly noteworthy, because they are incapable of infecting apple and pear trees (Asselin et al. 2008; De Ley et al. 1984; Evans 1996; Ries and Otterbacher 1977; Starr et al. 1951). At the same time, the majority of isolates originating from pome fruit trees were not pathogenic for raspberries and blackberries (De Ley et al. 1984; Ries and Otterbacher 1977). Only Evans (1996) reported the successful inoculation of raspberry canes with E. amylovora isolate originating from apple trees. Because of these differences, Starr et al. (1951) suggested the creation of a distinct taxon-E. amylovora f.sp. rubi for isolates infecting Rubus shrubs.

Different strains of E. amylovora, however, differ greatly among themselves in relation to the virulence to the same plant genotype (Cabrefiga and Montesinos 2005; Hevesi et al. 2000; Puławska et al. 2006; Sholberg et al. 2001). The pathogenicity of the bacteria is determined mainly by their capacity for the biosynthesis of exopolysaccharide (EPS) and proteins, especially harpin. EPS is a major component of bacterial ooze, often accompanying necroses and cankers on plants and its production is correlated to virulence of the strain (Ayers et al. 1979; Maes et al. 2001). This compound complex may contain amylovoran, levan, and glucan (Geider 2000). Around the bacterial cell, EPS creates a capsule to protect it from adverse environmental effects as well as from recognition of the pathogen by the immune system of the attacked plant. The loss of this coating also affects the activity of harpin-a protein built mainly of glycine. Harpin is an inducer of hypersensitivity reaction. Most importantly, it acts as a signaling molecule inducing programmed cell death of the host plant (Greenberg 1996).

Norelli et al. (1986) examined E. amylovora strains and found that they showed different virulence for different cultivars of apple trees. On the other hand, Schwartz et al. (1991) showed that only some strains of this bacterium inhibited the growth of pear cells in agar medium. This inhibition was related to their ability to produce dihydrophenylalanine (DPH) which is toxic to plants. Individual isolates can also differ in pathogenicity on pear fruitlets and their ability to induce a hypersensitivity reaction on tobacco. However, for most of the isolates, obtained results are generally positive in both tests. In some cases, a negative results of one or both of tests were achieved (De Ley et al. 1984; Vantomme et al. 1982).

Biochemical tests, serology and susceptibility to phages

Isolates of E. amylovora create a very homogeneous group in terms of biochemical and physiological properties (Dye 1981; Holt et al. 1994; Mergaret et al. 1984; Paulin 2000). However, some differences may exist between different isolates in the ability to use certain carbohydrates as carbon sources. Numerical analysis of metabolic profiles of different isolates of E. amylovora based on the BIOLOG system was done. The analysis can be used to differentiate a group of isolates from plants belonging to the subfamily Pomoideae, from the isolates originating from plants belonging to the genus Rubus. Among the latter group, two subgroups were distinguished: Rubus I and Rubus II (Kim et al. 1996). In case of strains from Bulgaria, it was found that 41 out of 95 carbon sources were differentially used by the strains and numerical analysis of BIOLOG results allowed to distinguish five groups within tested strains. However, no relationship to geographic origin or host-plant was found (Atanasova et al. 2007). In contrast, analysis of phenotypic features with application of BIOLOG and API kits was found not useful for intraspecific discrimination of Spanish E. amylovora isolates (Donat et al. 2007). Our research included studying of the phenotypic characteristics of E. amylovora isolates originating from Poland using API 50CH, API ZYM and API 20NE. We found that out of the 87 examined traits, some of the tested isolates differed only in their capacity to utilize melibiose, cellobiose, sorbitol, D-glucose, and L-arabinose (Puławska et al. 2006). Analysis of serological divergence confirmed also high heterogeneity of E. amylovora isolates (Vantomme et al. 1982; Manulis et al. 1998).

Erwinia amylovora isolates can also differ in susceptibility to bacteriophages, which were recognized as playing important role in epidemiology of fire blight (Erskine 1973). Several phages affecting E. amylovora strains were 
found (Schnabel and Jones 2001; Gill et al. 2003). They differed in genome size and restriction patterns as well as in host range. Not every E. amylovora strain tested was susceptible for each phage infection. It can be explained by clustered regularly interspaced short palindrome repeats (CRISPR)/Cas system-a defense system against mobile genetic elements of phages or plasmid origins (Sorek et al. 2008).

Analysis of fatty acids and proteins

The cells of most isolates of E. amylovora, regardless of their geographical origin and host plants, are similar in fatty acid content. Only strains isolated from Rubus plants have slightly more cyclic acids. However, isolates resistant to streptomycin have fewer of these acids and more saturated fatty acids than isolates susceptible to this antibiotic (Van der Zwet and Wells 1993). According to Żarnowski et al. (2002), the differences observed in fatty acid profiles of individual isolates of E. amylovora are sufficient to distinguish them from one another. Garrett et al. (1987) even found a correlation between the obtained profiles, and virulence of tested isolates. Ivanović et al. (2011) found that based on FAME analysis, Serbian isolates were clustered into three groups: $\alpha, \beta$, and $\gamma$. Cluster analysis revealed that group $\beta$ and $\gamma$ consisted only of strains isolated from northern Serbia, whereas all strains isolated from central or southern Serbia belonged to group $\alpha$. Wider application of the analysis of fatty acids in epidemiologic and taxonomic studies, however, requires very strict compliance with the procedures. Such strictness is necessary because the profiles obtained may be affected, inter alia, by the age of the bacteria and composition of the growth medium (Casano 1986). However, the analyzed protein profiles indicate the high homogeneity of European isolates of E. amylovora, originated from plants belonging to the subfamily Pomoideae. The small differences observed among isolates did not correlate with their virulence, geographic origin or host plant (De Ley et al. 1984, Vantomme et al. 1982).

\section{Streptomycin resistance}

In 1952, just 8 years after its discovery by Schatz et al. (1944), streptomycin was registered in the U.S. as a plant protection compound (Murneek 1952). Its efficacy against fire blight has been confirmed in many studies on different continents. E. amylovora strains, resistant to streptomycin were detected for the first time in the U.S. The first report on this subject comes from California in 1971 (Miller and Schroth 1972), soon more reports appeared from Oregon and Washington (Coyier and Covey 1975) and in subsequent years from other parts of the USA where streptomycin was also used for control of fire blight (Chiou and Jones 1991). Recently, strains of E. amylovora resistant to this antibiotic have also been discovered outside of North America, for example, in Egypt (El-Goorani et al. 1989), New Zealand (Thomson et al. 1993), Israel (Manulis et al. 1996), and Lebanon (Saad et al. 2000). Among the resistant strains, two major phenotypes-high and medium-resistant were found (Chiou and Jones 1995; Coyier and Covey 1975; McManus and Jones 1994). Strains with low level of resistance rarely occur in nature (Schroth et al. 1979).

The resistance to streptomycin in bacteria may have a dual background: a point mutation in the rps $\mathrm{L}$ gene encoding the ribosomal protein S12 or by acquisition of genes associated with resistance, which are located on mobile genetic elements, such as plasmids or transposons. It was found that $E$. amylovora isolates with high resistance to streptomycin, possess chromosomal mutation in the gene $r p s \mathrm{~L}$. This mutation prevents attachment of the antibiotic to the ribosome and thus inhibits protein synthesis. However, this kind of streptomycin resistance occurs rarely, e.g. it was found only in $3.4 \%$ streptomycin-resistant strains in Michigan (McGhee et al. 2011). More often, this feature is associated with the acquisition of strategic strA-strB genes located on plasmids or transposons. These genes allow the synthesis of aminoglycoside-modifying enzymes. Such enzymes alter the structure of streptomycin so that it cannot inhibit protein synthesis (Chiou and Jones 1991). strA-strB genes were found on the plasmid RSF1010, which occurs in different bacteria as well as in clinical strains of Gramnegative bacteria. Further studies showed that these genes were also found in Tn5393 transposon located on conjugal plasmid pEA34 occurring in E. amylovora (Chiou and Jones 1993). Until 1994, resistance to streptomycin associated with strategic strA-strB genes was observed only in Michigan, USA. Later strains of E. amylovora with plasmid pEa8.7 containing these genes, were discovered in California (Palmer et al. 1997).

\section{Analysis of nucleic acids}

\section{Analysis of plasmid DNA}

Application of molecular techniques in studies on the diversity of E. amylovora has allowed for demonstrating the differences in size of pEA29 plasmid. It was found that the size of plasmid pEA29 ranges from about 27.6 to about $34.9 \mathrm{~kb}$ (McGhee and Jones 2000). Restriction analysis of this plasmid revealed a relatively high homogeneity of the isolates from fruit trees and their otherness from raspberry isolates and the E. pyrifoliae bacteria that cause symptoms similar to fire blight in Asian pear varieties (Kim et al. 
1999). These bacteria differ from the typical strains in pathogenicity and host range of plants. Originally, there was a consensus among researchers that pEA29 plasmid is present in all isolates of E. amylovora (Bereswill et al. 1992; Falkenstein et al. 1988). No genes, responsible for the transfer and mobilization within the sequence of this plasmid in conjunction with its high stability, caused the belief that pEA29 should occur in all wild strains of E. amylovora. Therefore, the first attempts to use DNA analysis to identify and detect the pathogen was based on this plasmid (Bereswill et al. 1992; Llop et al. 2000; McManus and Jones 1995a). But, over time it appeared that E. amylovora can lose pEA29 without losing pathogenicity (Bereswill et al. 1995). Brown et al. (1996) did not receive any product from five isolates originating from raspberry, pear and apple trees after amplification with primers complementary to the plasmid. In their view, the negative result of PCRs was evidenced by the absence of pEA29. In addition, one of the acquired Gram-positive, unidentified isolates, also reacted with these primers. Such a reaction may indicate an earlier acquisition of pEA29 from E. amylovora. By contrast, a few isolates of E. amylovora without this plasmid were found in Egypt, Iran, Spain and the USA (Carey et al. 2011; Llop et al. 2006; Mohammadi et al. 2009). Also, it was found that another plasmid of approximately $65 \mathrm{~kb}$ (pEI70) present in one of these isolates, showed no homology with pEA29. Based on the analysis of the plasmid composition of European strains of E. amylovora, it was found that the plasmid pEI70 is quite common in E. amylovora on our continent. In some areas, for example in Poland, it was found in about $10 \%$ of the over 100 strains tested. In other areas such as in Belgium, this plasmid was found in almost all tested isolates. It is assumed that the plasmid may carry genes important for the virulence of E. amylovora (Llop et al. 2008).

Of the primers complementary to the pEA29 plasmid DNA, a few (Bereswill et al. 1992; Llop et al. 2000; McManus and Jones 1995a) allow the amplification of $0.9 \mathrm{~kb}$ plasmid fragment flanked by PstI digestion sites. Several authors, however, obtained products of different length in amplification with some of these primer sets (Brown et al. 1996; Kim et al. 1996; Lecomte et al. 1997). Restriction analysis of these products showed that in this plasmid fragment, an insertion which has the size of 30-90 bp occurs (Lecomte et al. 1997). Sequencing of this amplified fragment revealed a 8-bp short sequence repeats (SSR), which may be found in different isolates in 3-15 copies (Kim and Geider 1999; Ruppittsch et al. 2004; Schnabel and Jones 1998). The described phenomenon was assessed as unstable, for example, in stress conditions (Jock et al. 2003). Therefore, the analysis of SSR is not recommended in epidemiological studies and diagnostics (Jock et al. 2003; Kim and Geider 1999; Schnabel and Jones
1998). Different observations were noted by Ruppittsch et al. (2004). They analyzed 104 strains of E. amylovora isolated in Austria. They checked for stability in the number of repetitions of the previously described 8-bp sequence after repeated passage, and under stress. The vast majority of studies showed the number of repetitions of the SSR as being unchanged. Depending on the area of Austria, isolated strains possessed different numbers of SSR. Based on these results, Ruppittsch et al. (2004) came to the conclusion that fire blight does not spread from one source. Instead, the sources of infection were introduced several times over the years, after the first appearance of the disease in 1993 in this country.

Intensive research on the genome of $E$. amylovora revealed the presence of other plasmids in the cells of some isolates of this species. Foster et al. (2004) determined the nucleotide sequence and distribution of pEU30 plasmid (size $30.314 \mathrm{~kb}$ ) and the pEL60 plasmid (size $60.145 \mathrm{~kb}$ ). The presence of pEU30 plasmid was found in isolates from western USA, while pEL60 in isolates from Lebanon. Sequences of plasmids and genes located on them suggest that the smaller one is similar to other plasmids isolated from various bacteria associated with plants. The bigger one showed high similarity to plasmids occurring in the human intestinal bacteria. Analysis of genome sequence of the strain Ea273 (well-known and widely used in research) revealed the existence of another new plasmid called AMYP2 (size 71,487 bp) (Sebaihia et al. 2010). Recently, a new plasmid of about $60 \mathrm{kbp}$ has also been found in the E. amylovora strain isolated from Sorbus in Poland. Its partial sequence analysis shows no similarity to any sequence deposited in GenBank (J. Puławska, unpublished).

\section{Analysis of chromosomal DNA}

\section{Analysis of repetitive sequences-Rep-PCR}

Amplification of DNA regions located between repetitive extragenic palindromic (REP) sequences, enterobacterial repetitive intergenic consensus (ERIC), and BOX was one of the first techniques applied for estimation of E. amylovora genetic diversity (McManus and Jones 1995b). This technique was used both in diagnostics and in epidemiological studies (Louws et al. 1999; Versalovic et al. 1991). The application of this technique allowed McManus and Jones (1995b) to easily distinguish isolates originating from Rubus and Pomoideae plants. The latter proved to be very homogenous. DNA amplification of more than 170 isolates, mostly from the North American continent, allowed only 2-3 profiles to be obtained, depending on the primers used (the largest variation was obtained using ERIC primers). It should be noted, that irrespective of the primers used, one of the profiles obtained was always 
dominant. For the majority of isolates from Rubus plants, different profiles were obtained than for those isolates from fruit trees. Rico et al. (2008) also found little interest for the rep-PCR technique when determining the phylogenetic relationships between strains of E. amylovora. There was little diversity of the obtained amplification products, but very few reported polymorphic products allowed for the development of primers for amplification of marker containing DNA fragments. These primers can serve as a tool in epidemiological studies - for example, to track the spread of pathogen from a specific disease outbreak.

\section{Ribotyping}

McManus and Jones (1995b) amplified the DNA region located in the rrn operon, between genes encoding 16S rRNA and 23S rRNA (Gürtler and Stanisich 1996). Amplification of this region of the E. amylovora isolates allowed for easy distinction of Rubus isolates forming a homogeneous group. Also, isolates from fruit trees proved to be rather homogenous-amplification of DNA from about 170 isolates showed only three different profiles (McManus and Jones 1995b). Jeng et al. (1999) reported similar results of ribotyping where strains isolated from Rubus shrubs, and isolates derived from plants of the subfamily Pomoideae formed two homogeneous groups. Momol et al. (1999) used a modification of ribotyping. This modification consisted of additional digestion products obtained by using restriction enzymes (amplified ribosomal DNA restriction enzyme analysis, ARDREA). This procedure only allowed raspberry and blackberry isolates to be distinguished from isolates originating from other host plants. Garbeva et al. (1997), using the same technique, did manage to show variation among the isolates from fruit trees. They actually obtained distinct profiles for only 2 isolates, out of 14 tested.

\section{Sequence analysis of housekeeping and pathogenicity- related genes}

Kim et al. (1996) analyzed genomic DNA of selected isolates of E. amylovora using the enzyme EcoRI, and then conducted a hybridization with a probe including a group of $h r p$ genes. For all isolates from fruit trees, one profile was obtained. For isolates from the shrubs belonging to the genus Rubus two different profiles have been obtained. Sequence analysis of the gene $h r p \mathrm{~N}$ encoding harpin and amino acid sequence of the protein deduced from the nucleotide sequences, confirmed the greater diversity of American strains compared to European strains. The sequences of the gene were almost identical in European strains (Jock and Geider 2004). A study by Giorgi and
Scortichini (2005) on E. amylovora isolates originating from different continents confirmed that there was a greater variation in the gene $h r p \mathrm{~N}$ of bacteria isolated in North America where fire blight was discovered and described for the first time in the world. RFLP analysis of genes $h r p \mathrm{~N}$ and $d s p \mathrm{~A} / \mathrm{E}$ revealed significant differences between the strains isolated from plants of Rubus and Amelanchier, and those from the plants belonging to the family Maloidae (Giorgi and Scortichini 2005). Restriction fragment analysis of ams Bene (involved in the production of specific polysaccharide of E. amylovora-amylovoran) showed no differences between strains isolated in Poland (Puławska et al. 2006).

Analysis of housekeeping genes also confirmed the high homogeneity of E. amylovora. Waleron et al. (2002) amplified the rec $\mathrm{A}$ gene encoding recombinase $\mathrm{A}$ of nine isolates of E. amylovora, originated from fruit trees in various parts of the world. The amplification products were then digested with four restriction enzymes. For all isolates, however, the same profiles were obtained. Just a few nucleotide differences were found in $g r o E L$ sequences of E. amylovora strains isolated in apple and pear orchards in Michigan and strains from the western United States or from Rubus spp (McGhee et al. 2011).

\section{Random amplified polymorphic DNA}

For the study on genetic variation of E. amylovora, Momol et al. (1997) used the Random amplified polymorphic DNA (RAPD) technique (Williams et al. 1990). Profiles were obtained by amplification of DNA from 16 E. amylovora isolates from different geographical regions, with 6 random primers. This procedure allowed each of the isolates to be distinguished. At the same time isolates from Rubus plants and trees of the subfamily Pomoideae formed two groups. The similarity between these isolates, as determined by UPGMA and expressed by the Nei-Li coefficient, was approximately 0.7 (Momol et al. 1997). Brennan et al. (2002) applied the same primers to study isolates originating mainly from Ireland. Although most of the profiles obtained a similarity above 0.9 (Nei-Li coefficient, UPGMA method), some of the profiles differed significantly from the others. The RAPD technique also revealed the high homogeneity of E. amylovora isolates from other geographical regions (Keck et al. 2002; Manulis et al. 1998; Taylor and Hale 1998).

The RAPD was also used to examine the diversity of E. amylovora isolates from Poland. The study included 64 isolates, of which 50 were isolated during 1983-2002 from different host plants (apple, pear, quince, firethorn, hawthorn, and cotoneaster), from different regions of the country. The remaining 12 isolates originated from other European countries, including two from the Middle East. 
The studies confirmed the high homogeneity of the tested isolates. No correlation between the genetic diversity of isolates and their geographical origin or the plant from which they were isolated, was found (Puławska et al. 2006).

\section{Amplified fragment length polymorphism}

In an epidemiological study performed in Italy the amplified fragment length polymorphism (AFLP) technique was used. The use of AFLP led to the conclusion that the occurrence of fire blight in the provinces of Modena and Ferrara, was caused by a single introduction of E. amylovora (Minardi et al. 2000). Similar analysis of Austrian and Hungarian isolates of this bacterium did not show any differences between the isolates (Keck et al. 2002).

In Spain, an attempt was made to differentiate isolates of E. amylovora from different countries, using the rep-PCR (ERIC, BOX, IS50, and M13 primer) and the AFLP technique. Of the 23 tested isolates, 18 were not resolvable with the use of rep-PCR. The use of AFLP with 6 primers allowed for differentiation of the remaining 18. For all, except two strains, a unique combination of AFLP profiles was obtained (Rico et al. 2004). Extended study of both phenotypic and genotypic characteristics of 63 strains isolated in different regions of Spain, confirmed that from among all the techniques, the greatest distinction was achieved by using AFLP. This technique allowed the differentiation of bacteria according to their geographical origin. The results indicate that new outbreaks of fire blight in Spain are the result of multiple introductions of infected plant material or other sources of inoculum from different European countries (Donat et al. 2007).

\section{Pulse field gel electrophoresis}

Promising results were obtained using the pulse field gel electrophoresis (PFGE) technique (Jock et al. 2002; Zhang and Geider 1997; Zhang et al. 1998). Application of this technique after digestion of genomic DNA with $X b a \mathrm{I}$ endonuclease allowed six pattern types to be distinguished from among European isolates of E. amylovora. Use of the PFGE technique also showed a hypothetical spread of the disease: from the British Isles to Central Europe, separately to France and then to the Iberian Peninsula and to northern Italy; from western France to north-eastern Spain; from Egypt via the Middle East to Asia Minor, and then to the Balkans (Jock et al. 2002; Zhang and Geider 1997; Zhang et al. 1998). More detailed analysis of E. amylovora strains isolated in Serbia and Montenegro revealed three new patterns and indicated spread of E. amylovora across the Balkan Peninsula from the south to the north (Ivanović et al. 2010).
Unlike the European strains, PFGE profiles of strains from North America were much more diverse. European isolates can be classified into six different groups based on restriction profiles. Among North American isolates, only part were of the same profile as the isolates of E. amylovora from northern Spain, western France and England. Another group was identical to isolates from the Central Europe. The remaining isolates were characterized by a high degree of profile diversification, unprecedented in Europe. This observation led to the hypothesis that fire blight had spread throughout the world, by escaping from North America only a few times (Jock et al. 2002).

\section{Genome analysis and derivative techniques}

Comparative genome analysis of two E. amylovora strains: European-CFBP 1430 and American-Ea273, confirmed high genetic similarity within this species. The similarity of both genomes was estimated as $99.99 \%$ with only a low number of nucleotide differences (Smits et al. 2010). For differentiation of such a monomorphic pathogens, analysis of single nucleotide polymorphisms (SNPs) has been found suitable as well as multi-locus variable number of tandem repeats analysis (MLVA) and CRISPR analysis.

Single nucleotide differences in the genes: $g a l \mathrm{E}, a c r \mathrm{~B}$, and $h r p \mathrm{~A}$ were found between individual E. amylovora strains from North America and from Europe, the Mediterranean region, Australia, and New Zealand. This single nucleotide polymorphic site allowed for the designing of primers differentiating these two groups of strains. Regarding the raspberry strains, which have only been isolated in North America, the nucleotide sequences in galE, $a c r \mathrm{~B}$, and $h r p \mathrm{~A}$ were consistent with the sequences of Ea273 strain isolated from Malus in the primer regions, in the USA, while other base changes were present in other parts of the genes (Gehring et al. 2011).

Tandem repeat structures have been recognized as a highly polymorphic loci in all organisms. In bacteria, they usually have a length of one to several hundred nucleotides and can be present in coding and intergenic regions. Silico analysis of E. amylovora chromosome for the presence of variable number of tandem repeats (VNTR) confirmed their presence at a density slightly lower than in other analyzed plant pathogenic bacteria. MLVA applied to 600 E. amylovora strains of different geographical origins revealed relatively high diversity. Moreover analysis of isolates from two fire blight outbreaks in Slovenia (in 2003 and 2007), showed just a few high-frequency genotypes mixed with a variety of low-frequency genotypes (Dreo et al. 2010).

Clustered regularly interspaced short palindrome repeats consist of identical repeated DNA sequences, interspaced by highly variable sequences called spacers. This newly recognized genetic structure plays the role of a defense 
system against mobile genetic elements of phages or plasmid origins (Sorek et al. 2008) and it is found to be very diverse among $E$. amylovora strains. McGhee and Sundin (2011) found that the CRISPR repeat sequence among E. amylovora strains consists of $29 \mathrm{bp}$ and is universal despite host range, geographic distribution, or array number. To date, a total of 357 unique spacers have been identified in CRISPR arrays present in E. amylovora. Spacer patterns from Michigan strains were mainly distinct from strains isolated in western USA. But strains from France and Lebanon included in the study, shared the same patterns as some strains from Michigan. Spacer sequence identities to foreign genetic elements included plasmids from E. tasmaniensis and Salmonella enterica. Rezzonico et al. (2011) found 18 different CRISPR genotypes within a collection of 37 cosmopolitan strains. Within them, a total of 454 distinctive CRISPR spacers were identified. The strains isolated from Spiraeoideae, clustered in three major CRISPR groups. Both group II and group III were composed exclusively from bacteria originating from the United States. Group I generally contained strains from Europe, New Zealand, and the Middle East. The authors concluded that these results suggest that the genotype of the causative agent of fire blight in Pomaceae was selectively enriched from the broader genetic pool, which is present on wild host plants in North America.

\section{Conclusion}

Erwinia amylovora strains belong to one of the most homogeneous species of plant pathogenic bacteria in terms of biochemical and genetic characters, but differ in terms of virulence. Clear differences were observed only between isolates derived from raspberries and blackberries, and isolates originating from apple and pear trees and other host plants. In areas where the measures on the basis of streptomycin against fire blight are applied, some strains show resistance to this antibiotic. Depending on the type of mechanism responsible for the resistance, the bacteria strains were divided into high and medium resistance. Studies on the genetics of E. amylovora showed greater diversity among the strains from North America, where fire blight was first described, than among European strains. Recent studies show that E. amylovora's content of plasmid DNA may vary. Furthermore, some plasmids, e.g. that discovered in Spain-pEI70, may involve genes important for pathogenicity of bacteria other than those already known to be responsible for the synthesis of: exopolysaccharides, siderophores, and proteins such as harpins. Despite considerable progress in the research of the functions of the genes, their overall importance has not yet been identified. Out of all molecular techniques used, AFLP and those developed on the basis of released pan-genome

Table 1 Differentiation of E. amylovora isolates on the basis of their genomic DNA

\begin{tabular}{|c|c|c|}
\hline Method & Result & Reference \\
\hline \multirow[t]{2}{*}{ Rep-PCR } & $\begin{array}{l}\text { Differentiation between isolates from Rubus spp. and isolates from } \\
\text { Pomoidae }\end{array}$ & McManus and Jones (1995b) \\
\hline & Polymorphic products were used as DNA markers & Rico et al. (2008) \\
\hline \multirow[t]{2}{*}{ Ribotyping } & $\begin{array}{l}\text { Differentiation between isolates from Rubus spp. and from } \\
\text { Pomoidae }\end{array}$ & $\begin{array}{l}\text { Gürtler and Stanisich (1996), Jeng et al. (1999), } \\
\text { McManus and Jones (1995b), Momol et al. (1999) }\end{array}$ \\
\hline & Slight differentiation of isolates from fruit trees & Garbeva et al. (1997) \\
\hline \multirow{2}{*}{$\begin{array}{l}\text { RFLP of } \\
\text { genomic } \\
\text { DNA + PFGE }\end{array}$} & $\begin{array}{l}\text { Distinction of different types among European isolates and } \\
\text { presentation of hypothetical ways of spreading of the pathogen }\end{array}$ & $\begin{array}{l}\text { Jock et al. (2002), Ivanović et al. (2010), Zhang and } \\
\text { Geider (1997), Zhang et al. (1998) }\end{array}$ \\
\hline & Diversity among isolates from North America & Jock et al. (2002) \\
\hline $\begin{array}{l}\text { Housekeeping } \\
\text { genes }\end{array}$ & High homogeneity between tested strains & McGhee et al. (2011), Waleron et al. (2002) \\
\hline $\begin{array}{l}\text { Pathogenicity- } \\
\text { related genes }\end{array}$ & $\begin{array}{l}\text { Greater diversity of American strains compared to European } \\
\text { strains. Differences between the strains isolated from plants of } \\
\text { Rubus and Amelanchier, and bacteria from the plants belonging } \\
\text { to the family Maloidae }\end{array}$ & $\begin{array}{l}\text { Kim et al. (1996), Giorgi and Scortichini (2005), Jock } \\
\text { and Geider (2004), Puławska et al. (2006) }\end{array}$ \\
\hline \multirow[t]{2}{*}{ RAPD } & Distinction between isolates from Rubus spp. and from Pomoidae & Momol et al. (1997) \\
\hline & High homogeneity among isolates tested & $\begin{array}{l}\text { Brennan et al. (2002), Keck et al. (2002), Manulis et al. } \\
\text { (1998), Puławska et al. (2006), Taylor and Hale } \\
\text { (1998) }\end{array}$ \\
\hline \multirow[t]{2}{*}{ AFLP } & $\begin{array}{l}\text { Lack of differences between isolates from Italy, Austria and } \\
\text { Hungary }\end{array}$ & Keck et al. (2002), Minardi et al. (2000) \\
\hline & Differentiation of isolates according to geographic origin in Spain & Donat et al. (2007), Rico et al. (2004) \\
\hline MLVA & High diversity revealed among isolates tested & Dreo et al. (2010) \\
\hline CRISPR & High diversity revealed among isolates tested & Rezzonico et al. (2011) \\
\hline
\end{tabular}


E. amylovora sequences: multi- MLVA and CRISPRseem to be the most promising in differentiation of strains of fire blight pathogen (Table 1).

\section{References}

Agrios GN (2005) Plant pathology, 5th edn. Elsevier Academic Press, Amsterdam

Atanasova I, Stefanova K, Kabadjova P, Tishkov S, Dimitrov Z, Bogatzevska N, Moncheva P (2007) Phenotypic diversity of Erwinia amylovora in Bulgaria. Z Naturforsch C 62:857-868

Asselin JE, Yip KN, Beer SV (2008) eopl differs in strains of Erwinia amylovora that differ in host specificity. Acta Hortic 793:213-214

Ayers AR, Ayers SB, Goodman RN (1979) Extracellular polysaccharide of Erwinia amylovora - correlation with virulence. Appl Environ Microbiol 38:659-666

Bereswill S, Bugert P, Bruchmüller I, Geider K (1995) Identification of fire blight pathogen, Erwinia amylovora, by PCR assays with chromosomal DNA. Appl Environ Microbiol 61:2636-2642

Bereswill S, Pahl A, Bellemann P, Zeller W, Geider K (1992) Sensitive and species-specific detection of Erwinia amylovora by polymerase chain reaction analysis. Appl Environ Microbiol 58:3522-3526

Brennan JM, Doohan FM, Egan D, Scanlan H, Hayes D (2002) Characterisation and differentiation of Irish Erwinia amylovora isolates. J Phytopathol 150:414-422

Brown EW, Janisiewicz W, Van der Zwet T (1996) Preliminary phenotypic and genetic differentiation of the fire blight bacterium, Erwinia amylovora. Acta Hortic 411:199-203

Cabrefiga J, Montesinos E (2005) Analysis of aggressiveness of Erwinia amylovora using disease-dose and time relationships. Phythopathlogy 95:1430-1437

Carey A, Pusey P, Smith TJ, Loper J, Stockwell V (2011) Plasmid content of isolates of Erwinia amylovora from orchards in Washington and Oregon in the USA. Acta Hortic 896:123-126

Casano FJ (1986) Effect of growth medium and physiological age on the fatty acid analysis of Erwinia amylovora. Acta Hortic 217:41-42

Chiou CS, Jones AL (1991) The analysis of plasmid-mediated streptomycin resistance in Erwinia amylovora. Phytopathology $81: 710-714$

Chiou CS, Jones AL (1993) Nucleotide sequence analysis of a transposon (Tn5393) carrying streptomycin resistance genes in Erwinia amylovora and other gram-negative bacteria. J Bacteriol 175:732-740

Chiou CS, Jones AL (1995) Molecular analysis of high-level streptomycin resistance in Erwinia amylovora. Phytopathology 85:324-328

Coyier DL, Covey RP (1975) Tolerance of Erwinia amylovora to streptomycin sulphate in Oregon and Washington. Plant Dis Rep 59:849-852

De Ley J, Vantomme R, Swings J, Kersters K, Rijckaert C, Goor M, Mergaert J, Green J (1984) Research report on Erwinia amylovora. Acta Hortic 151:241-248

Donat V, Biosca EG, Peñalver J, López MM (2007) Exploring diversity among Spanish strains of Erwinia amylovora and possible infection sources. J Appl Microbiol 103:1639-1649

Dreo T, Frey J, Smits T, Ravnikar M, Duffy B (2010) Analysis of variable number of tandem repeats in Erwinia amylovora as an epidemiological and biodiversity tool. In: Book of abstracts 12th international workshop on fire blight, Warsaw, Poland, August $16-20$, p 27
Dye DW (1981) A numerical taxonomic study of the genus Erwinia. N Z J Agric Res 24:223-229

El-Goorani MA, El-Kasheir HMA, Shoeib AA, Hassanein FM (1989) Distribution of streptomycin resistant strains of Erwinia amylovora in Egypt during 1988. J Phytopathol 127:69-74

Erskine JM (1973) Characteristics of Erwinia amylovora bacteriophage and its possible role in epidemiology of fire blight. Can J Microbiol 19:837-845

Evans IR (1996) Fire blight of raspberries in Alberta. Acta Hortic 411:69-72

Falkenstein H, Bellemann P, Walter S, Zeller W, Geider K (1988) Identification of Erwinia amylovora, the fireblight pathogen, by colony hybridisation with DNA from plasmid pEA29. Appl Environ Microbiol 54:2798-2802

Foster GC, McGhee GC, Jones AL, Sundin GW (2004) Nucleotide sequences, genetic organization, and distribution of pEU30 and pEL60 from Erwinia amylovora. Appl Environ Microbiol 70:7539-7544

Garbeva P, Crepel C, Maes M (1997) Genomic variation within the Erwinia amylovora species. Med Fac Landbouww Univ Gent 62/3b:937-942

Garrett CME, Blake PS, Fletcher DA, Austin DJ (1987) Preliminary discrimination of Erwinia amylovora strains by fatty acid profiling. Acta Hortic 217:63-69

Gehring I, Geider K, Rausch T (2011) Differentiation of Erwinia amylovora and E. pyrifoliae strains with single nucleotide polymorphisms and by synthesis of dihydrophenyalanine. Acta Hortic 896:95-98

Geider K (2000) Exopolysaccharides of Erwinia amylovora: structures, biosynthesis, regulation, role in pathogenicity of amylovoran and levan. In: Vanneste JL (ed) Fire blight. The disease and its causative agent, Erwinia amylovora. CABI Publishing, Wallingford, pp 141-162

Gill JJ, Svircev AM, Smith R, Castle AJ (2003) Bacteriophages of Erwinia amylovora. Appl Environ Microbiol 69:2133-2138

Giorgi S, Scortichini M (2005) Molecular characterization of Erwinia amylovora strains from different host plants through RFLP analysis and sequencing of $h r p \mathrm{~N}$ and $d s p \mathrm{~A} / \mathrm{E}$ genes. Plant Pathol 54:789-798

Greenberg JT (1996) Programmed cell death: a way of life for plants. Proc Natl Acad Sci USA 93:12094-12097

Gürtler V, Stanisich VA (1996) New approaches to typing and identification of bacteria using the $16 \mathrm{~S}-23 \mathrm{~S}$ rDNA spacer region. Microbiology 142:3-16

Hevesi M, Papp J, Jámbor-Benczúr E, Kaszáné-Csizmár K, Pozsgai I, Gazdag G, Balla I (2000) Testing the virulence of some Hungarian Erwinia amylovora strains on in vitro cultured apple rootstocks. Int J Hortic Sci 6:52-55

Holt JG, Krieg NR, Sneath PHA, Stanley JT, Williams ST (1994) Bergey's manual of determinative bacteriology, 9th edn. Williams \& Wilkins, Baltimore

Ivanović M, Gašić K, Obradovic A, Dickstein E, Jones JB, Gavrilović V, Balaž J (2011) Identification and differentiation of Erwinia amylovora using fatty acid analysis and BIOLOG. Acta Hortic 896:65-71

Ivanović M, Minsavage G, Jones J, Gašić K, Gavrilović V, Balaž J, Obradović A (2010) Grouping of Erwinia amylovora strains from Serbia and Montenegro based on PFGE. In: Book of abstracts 12th international workshop on fire blight, Warsaw, Poland, August 16-20, p 28

Jeng RS, Belivera L, Hubbes M, Svircev AM, Myers AL (1999) The use of $16 \mathrm{~S}$ and $16 \mathrm{~S}-23 \mathrm{~S}$ rRNA internal transcribed spacers to detect and differentiate Erwinia amylovora. Acta Hortic 489:49-54

Jock S, Donat V, López MM, Bazzi C, Geider K (2002) Following spread of fire blight in Western, Central and Southern Europe by 
molecular differentiation of Erwinia amylovora strains with PFGE analysis. Environ Microbiol 4:106-114

Jock S, Geider K (2004) Molecular differentiation of Erwinia amylovora strains from North America and of two Asian pear pathogens by analyses of PFGE patterns and $h r p \mathrm{~N}$ genes. Environ Microbiol 6(5):480-490

Jock S, Jacob T, Kim W-S, Hildebrand M, Vosberg H-P, Geider K (2003) Instability of short-sequence DNA repeats of pear pathogenic Erwinia strains from Japan and Erwinia amylovora fruit tree and raspberry strains. Mol Gen Genomics 268:739-749

Jones AL, Schnabel EL (2000) The development of streptomycinresistant strains of Erwinia amylovora. In: Vanneste JL (ed) Fire blight. The disease and its causative agent, Erwinia amylovora. CABI Publishing, Wallingford, pp 235-251

Keck M, Hevesi M, Ruppitsch W, Ströger A, Richrer S (2002) Spread of fire blight in Austria and Hungary-variability of Erwinia amylovora strains. Plant Prot Sci 38(1):49-55

Kim JH, Beer SV, Zumoff CH, Laby HL, Gustafson HL, Aldwinckle HS (1996) Characterization of Erwinia amylovora strains from different hosts and geographical areas. Acta Hortic 411:183-185

Kim WS, Geider K (1999) Analysis of variable short-sequence DNA repeats on the $29 \mathrm{~kb}$ plasmid of Erwinia amylovora. Eur J Plant Pathol 103:703-713

Kim WS, Hildebrand M, Jock S, Geider K (2001) Molecular comparison of pathogenic bacteria from pear trees in Japan and the fire blight pathogen Erwinia amylovora. Microbiology 147:2951-2959

Kim WS, Rhim SL, Völksch B, Gardan L, Paulin JP, Jock S, Geider K (1999) Characterization of a new Erwinia species affecting Asian pear trees. Acta Hortic 489:201-205

Lecomte P, Manceau Ch, Paulin J-P, Keck M (1997) Identification by PCR analysis on plasmid pEA29 of isolates of Erwinia amylovora responsible of an outbreak in Central Europe. Eur J Plant Pathol 103:91-98

Llop P, Bonaterra A, Peñalver J, López MM (2000) Development of a highly sensitive nested-PCR procedure using single closed tube for detection of Erwinia amylovora in asymptomatic plant material. Appl Environ Microbiol 66:2071-2078

Llop P, Donat V, Rodríguez M, Cabrefiga J, Ruz L, Palomo JL, Montesinos E, López MM (2006) An indigenous virulent strain of Erwinia amylovora lacking the ubiquitous plasmid pEA29. Phytopathlogy 96:900-907

Llop P, González R, Pulawska J, Bultreys A, Dreo T, López MM (2008) The new plasmid pEI70 is present in Erwinia amylovora European strains. Acta Hortic 793:131-136

Louws FJ, Rademaker JLW, Bruijn FJ (1999) The three Ds of PCRbased genomic analysis of phytobacteria: diversity, detection, and disease diagnosis. Ann Rev Phytopathol 37:81-125

Maes M, Orye K, Bobev S, Devreese B, Van Beeumen J, De Bruyn A, Busson R, Herdewijn P, Morreel K, Messens E (2001) Influence of amylovoran production on virulence of Erwinia amylovora and a different amylovoran structure in E. amylovora isolates from Rubus. Eur J Plant Pathol 107:839-844

Manulis S, Kleitman F, Dror O, Davis I, Zutra D (1998) Characterization of Erwinia amylovora population in Israel. Phytoparasitica 26:39-46

Manulis S, Zutra D, Ga'ash D, Kleitman F, Dror O, Elisha S, David I, Rav-David D, Zilberstaine M, Herzog Z, Shabi E (1996) Streptomycin resistance of Erwinia amylovora in Israel and occurrence of blossom blight in the autumn. Phytoparasitica 24:161

McGhee GC, Guasco J, Bellomo LM, Blumer-Schuette SE, Shane WW, Irish-Brown A, Sundin GW (2011) Genetic analysis of streptomycin-resistant (Sm-R) strains of Erwinia amylovora suggests that dissemination of two genotypes is responsible for the current distribution of Sm-R E. amylovora in Michigan. Phytopathology 101:182-191
McGhee GC, Jones AL (2000) Complete nucleotide sequence of ubiquitous plasmid pEA29 from Erwinia amylovora strain Ea88: gene organization and interspecies variation. Appl Environ Microbiol 66:4897-4907

McGhee GC, Sundin G (2011) Erwinia amylovora CRISPR elements provide new tools for evaluating strain diversity and microbial source tracking. Acta Hortic 896:99-107

McManus PS, Jones AL (1994) Epidemiology and genetic analysis of streptomycin resistant Erwinia amylovora from Michigan and evaluation of oxytetracycline for control. Phytopathology 84:627-633

McManus PS, Jones AL (1995a) Detection of Erwinia amylovora by nested PCR, PCR-dot-blot and reverse-blot hybridisation. Phytopathology 85:618-623

McManus PS, Jones AL (1995b) Genetic fingerprinting of Erwinia amylovora strains isolated from tree-fruit crops and Rubus spp. Phytopathology 85:1547-1553

Mergaret J, Verdonock L, Kersters K, Swings J, Boeufgras J-M, de Lay J (1984) Numerical taxonomy of Erwinia amylovora species using API systems. J Gen Microbiol 130:1893-1910

Miller TD, Schroth MN (1972) Monitoring the epiphytic population of Erwinia amylovora on pear with selective medium. Phytopathology 62:1175-1182

Minardi TF, Stefani P, Mazzucchi U (2000) Erwinia amylovora isolates associated with 1997 fire blight epidemic in the Po Valey derivated from the same clone. In: Book of abstracts 9th congress of the European foundation for plant pathology, "biodiversity in plant pathology". Taromina, 18 Sept, p 37

Mohammadi M, Moltmann E, Zeller W, Geider K (2009) Characterization of naturally occurring Erwinia amylovora strains lacking the common plasmid pEA29 and their detection with real-time PCR. Eur J Plant Pathol 124:293-302

Momol MT, Aldwinckle HS (2000) Genetic diversity and host range of Erwinia amylovora. In: Vanneste JL (ed) Fire blight. The disease and its causative agent, Erwinia amylovora. CABI Publishing, Wallingford, pp 55-72

Momol MT, Momol EA, Lamboy WF, Norelli JL, Beer SV, Aldwinckle HS (1997) Characterization of Erwinia amylovora strains using random amplified polymorphic DNA fragments (RAPDs). J Appl Microbiol 82:339-398

Momol EA, Momol MT, Norelli JL, Beer SV, Burr TJ, Aldwinckle HS (1999) Relatedness of Erwinia amylovora strains based on amplified 16S-23S ribosomal DNA restriction enzyme analysisARDREA. Acta Hortic 489:55-59

Murneek AE (1952) Thiolutin as a possible inhibitor of fire blight. Phytopathology 42:57

Norelli JL, Aldwinckle HS, Beer SV (1986) Differential susceptibility of Malus spp. Robusta 5, Novole, and Ottawa 523 to infection by Erwinia amylovora. Plant Dis 70:1017-1019

Palmer EL, Teviotdale BL, Jones AL (1997) A relative of the broadhost-range plasmid RSF1010 detected in Erwinia amylovora. Appl Environ Microbiol 63:4604-4607

Paulin JP (2000) Erwinia amylovora: general characteristic. In: Vanneste JL (ed) Fire blight. The disease and its causative agent, Erwinia amylovora. CABI Publishing, Wallingford, pp 87-115

Puławska J, Kielak K, Sobiczewski P (2006) Phenotypic and genetic diversity of selected Polish Erwinia amylovora strains. Acta Hortic 704:439-444

Rezzonico F, Smits THM, Duffy B (2011) Diversity, evolution and functionality of clustered regularly interspaced short palindromic repeat (CRISPR) regions in the fire blight pathogen Erwinia amylovora. Appl Environ Microbiol 77:3819-3829

Rico A, Fuhrer ME, Ortiz-Barredo A, Murillo J (2008) Polymerase chain reaction fingerprinting of Erwinia amylovora has a limited phylogenetic value but allows the design of highly specific molecular markers. Phytopathology 98:260-269 
Rico A, Ortiz-Barredo A, Ritter E, Murillo J (2004) Genetic characterization of Erwinia amylovora strains by amplified fragment length polymorphism. J Appl Microbiol 96:302-310

Ries SM, Otterbacher AG (1977) Occurrence of fire blight on thornless blackberry in Illinois. Plant Dis Rep 61:232-235

Ruppittsch W, Stoeger A, Keck M (2004) Stability of short sequence repeats and their application for the characterization of Erwinia amylovora strains. FEMS Microbiol Lett 234:1-8

Saad AT, Hana L, Choueiri E (2000) Evaluation of streptomycin and oxytetracycline resistance of Erwinia amylovora populations in Lebanon. Phytopathology 90:S68

Schatz A, Bugie E, Waksman SA (1944) Streptomycin, a substance exhibiting antibiotic activity against Gram-positive and Gramnegative bacteria. Proc Soc Exp Biol Med 55:66-69

Schnabel EL, Jones AL (1998) Instability of pEA29 marker in Erwinia amylovora previously used for strain classification. Plant Dis 82:1334-1336

Schnabel EL, Jones AL (2001) Isolation and characterization of five Erwinia amylovora bacteriophages and assessment of phage resistance in strains of Erwinia amylovora. Appl Environ Microbiol 67:59-64

Schroth MN, Thomson SV, Moller WJ (1979) Streptomycin resistance in Erwinia amylovora. Phytopathology 69:565-568

Schwartz T, Brenhard F, Theiler R, Geider K (1991) Diversity of the fire blight pathogen in production of dihydrophenylalanine, a virulence factor of some Erwinia amylovora strains. Phytopathology 81:873-878

Sebaihia M, Bocsanczy AM, Biehl BS, Quail MA, Perna NT, Glasner JD, DeClerck GA, Cartinhour S, Schneider DJ, Bentley SD, Parkhill J, Beer SV (2010) Complete genome sequence of the plant pathogen Erwinia amylovora strain ATCC 49946. J Bacteriol 192:2020-2021

Sholberg PL, Bedford KE, Haag P, Randall P (2001) Survey of Erwinia amylovora isolates from British Columbia for resistance to bactericides and its virulence on apple. Can J Plant Pathol 23:60-67

Smits THM, Rezzonico F, Kamber T, Blom J, Goesmann A, Frey JE, Duffy B (2010) Complete genome sequence of the fire blight pathogen Erwinia amylovora CFBP 1430 and comparison to other Erwinia spp. Mol Plant Microbe Interact 23:384-393

Sorek R, Kunin V, Hugenholtz P (2008) CRISPR - a widespread system that provides acquired resistance against phages in bacteria and archaea. Nat Rev Microbiol 6:181-186
Starr MP, Cardona C, Folsom D (1951) Bacterial fire blight of raspberry. Phytopathology 41:915-919

Taylor RK, Hale CN (1998) Identification and characterisation of isolates of Erwinia amylovora from cotoneaster in Australia. Aust Biotechnol 6:353-356

Thomson SV, Gouk SC, Vanneste JL, Hale CN, Clark RG (1993) The presence of streptomycin resistant strains of Erwinia amylovora in New Zealand. Acta Hortic 338:223-230

Van der Zwet T, Keil HL (1979) Fire blight—a bacterial disease of rosaceous plants. Agricultural Handbook 510, U.S. Department of Agriculture, Washington DC

Van der Zwet T, Wells JM (1993) Application of fatty acid class analyses for the detection and identification of Erwinia amylovora. Acta Hortic 338:233

Vanneste JL (1995) Erwinia amylovora. In: Singh US, Singh RP, Kohmoto K (eds) Pathogenesis and host specificity in plant diseases: histopathological, biochemical, genetic and molecular bases, vol1, prokaryotes. Pergamon Press, Oxford, pp 21-41

Vantomme R, Swings J, Goor M, Kersters K, De Ley J (1982) Phytopathological, serological, biochemical and protein electrophoresis characterisation of Erwinia amylovora strains isolated in Belgium. Phytopathology 103:349-360

Versalovic J, Koeuth T, Lupski JR (1991) Distribution of repetitive DNA sequences in eubacteria and application to fingerprinting of bacterial genomes. Nucl Acids Res. 19:6923-6931

Waleron M, Waleron K, Podhajska AJ, Łojkowska E (2002) Molecular comparison of pathogenic bacteria from pear trees in Japan and the fire blight pathogen Erwinia amylovora. Microbiology 147:2951-2959

Williams JGK, Kubelik AR, Livak KJ, Rafalski JA, Tingey SV (1990) DNA polymorphism amplified by arbitrary primers are useful as genetic markers. Nucl Acid Res 18:6531-6535

Zhang Y, Geider K (1997) Differentiation of Erwinia amylovora strains by pulsed-field gel electrophoresis. Appl Environ Microbiol 63:4421-4426

Zhang Y, Merighi M, Bazzi C, Geider K (1998) Genomic analysis by pulsed-field gel electrophoresis of Erwinia amylovora strains from the Mediterranean region including Italy. J Plant Pathol 80:225-232

Żarnowski R, Lewicka T, Ellis RJ (2002) Evaluation of natural diversity among Erwinia amylovora isolates on the basis of total cellular protein and fatty acid patterns. Acta Hortic 590:185-192 